\title{
Teams Games Tournament Assisted by Question Card Increases Student Knowledge Competence in Science Learning
}

\author{
I Kadek Dwi Oktayana Mahardika1, Made Putra² \\ ${ }_{12}$ Program Studi Pendidikan Guru Sekolah Dasar, Fakultas Ilmu Pendidikan, Universitas Pendidikan Ganesha, Bali, Indonesia
}

\author{
A RT I CLEINFO \\ Article history: \\ Received 2 Juni 2020 \\ Received in revised form \\ 12 Juli 2020 \\ Accepted 10 Agustus 2020 \\ Available online 28 Agustus \\ 2020 \\ kata kunci: \\ TGT, question card, \\ kompetensi pengetahuan \\ IPA \\ keywords: \\ TGT, question card, science \\ knowledge
}

\begin{abstract}
A B S T R A K
Rendahnya kompetensi pengetahuan IPA siswa yang disebabkan oleh kurang optimalnya penggunaan model pembelajaran yang inovatif serta kurangnya menggunakan media pembelajaran. Tujuan dari penelitian ini yaitu untuk mengkaji pengaruh dari model pembelajaran Teams Games Tournament berbantuan Media Question Card terhadap kompetensi pengetahuan IPA siswa kelas IV. Jenis penelitian ini merupakan eksperimen semu dengan desain penelitian nonequivalent control group design. Populasi dari penelitian ini siswa kelas IV dengan jumlah siswa keseluruhan 392 orang. Sampel ditentukan dengan teknik random sampling. Sampel dalam penelitian ini adalah siswa kelas IV dengan jumlah sampel kelas 34 siswa sebagai kelompok eksperimen dan siswa kelas IV dengan jumlah sampel kelas 33 siswa sebagai kelompok kontrol. Pengumpulan data kompetensi pengetahuan IPA dilakukan dengan metode tes dan instrumen yang digunakan berupa tes objektif pilihan ganda biasa. Data yang diperoleh dianalisis dengan menggunakan uji-t. Hasil analisis
\end{abstract} menunjukkan bahwa terdapat perbedaan yang signifikan model pembelajaran teams games tournament berbantuan media question card terhadap kompetensi pengetahuan IPA dengan pembelajaran konvensional siswa kelas IV SD. Berdasarkan hasil analisis data diperoleh nilai thitung $=3,245$ pada taraf signifikansi $5 \%$ dan dk $=65$ diperoleh nilai $t_{\text {tabel }}=1,997$ sehingga thitung $=3,25>t_{\text {tabel }}=1,997$. Berdasarkan kriteria pengujian, maka $H_{0}$ ditolak dan $H_{a}$ diterima. Dengan demikian dapat disimpulkan, model pembelajaran Teams Games Tournament berbantuan media Question Card berpengaruh terhadap kompetensi pengetahuan IPA siswa kelas IV SD.

\begin{abstract}
A B S T R A C T
The low competence of students' science knowledge is caused by the lack of optimal use of innovative learning models and the lack of using learning media. The purpose of this study was to examine the effect of the Teams Games Tournament learning model assisted by the Media Question Card on the scientific competence of science students in fourth grade elementary. This type of research was a quasi-experimental research design with a nonequivalent control group design. The population of this study was the fourth-grade students with a total of 392 students. The sample was determined by a random sampling technique. The sample in this study was class IV with a total sample of class 34 students as the experimental group and class IV with a class sample of 33 students as the control group. The science competency data collection was done by the test method and the instrument used was an ordinary multiple-choice objective test. The data obtained were analyzed using a t-test. The results of the analysis showed that there were significant differences in the learning models of team's games tournament assisted by the media question card to the scientific competence of science with conventional learning of fourth-grade students. Based on the results of data analysis obtained $t_{\text {count }}=3.245$ at a significance level of $5 \%$ and $d k=65$ obtained $t_{\text {table }}=1.997$ so $t_{\text {count }}=3.25>t_{\text {table }}=1.997$. Based on the testing criteria, it is rejected and accepted. Thus, it can be concluded, the Teams Games Tournament learning model assisted by the Question Card media influences the science knowledge competence of fourth-grade.
\end{abstract}

\section{Introduction}

Competencies that need to be developed are science competencies. According to Permendiknas No.22 Tahun 2006 regard to the meaning of Science, the study of natural events, Science is not only a concept but also a process of discovery. Science is one of the subjects in Indonesia's curriculum education. Science is a human effort to study the universe through observation and can be explained (Susanto, 2016). Natural Science is one of the subjects found at the elementary school level (Setianingsih, 2019). Science has a very important role in human life, because our life is very dependent on nature, substances contained in nature, and all kinds of symptoms that occur in nature (Awang, 2015). The characteristic of science learning is that contains value, attitudes

Copyright (C) Universitas Pendidikan Ganesha. All rights reserved. 
and processes, science as a process skill with observation activities (Sulthon, 2016). Science lessons are useful for students to study the relationship between humans and nature by observing and collecting natural concepts (Ariyanto, 2016).

Science learning should be student-centered and make students active in learning process, in classroom learning process it is only teacher-centered and only on rote teaching without any meaningful learning concept. In explaining the subject matter, the teacher does not apply various models and learning media, the teacher tends to explain the material orally so that students feel bored quickly. (Insani, 2016) argues that the lack of innovation learning models and media by teachers make students become passive in the learning process. It can be seen when the learning process takes place, students do not pay attention to the teacher's explanation and do not focus on the learning process, so the atmosphere becomes uncomfortable and many students do not understand the material delivered. This opinion is in line with (Devitasari, 2014) who stated that science learning in class tends to be taught conventionally, explained verbally and given monotonous assignments. The application of conventional learning causes students to get bored quickly and learning becomes meaningless, so conventional learning is less effective. The teaching provided by the teacher to students is not efective to develop children's abilities and the lack of opportunities to argue in front of the class, so that many students become passive. (Muakhirin, 2015) argues that having material is very important because it related to nature and the life of the universe, but in delivering material in the classroom the teacher still uses the oral method so that students cannot receive the information from the teacher properly.

This problem also occurs in SD Gugus RA. Kartini, Denpasar Barat. The science learning process is not as expected because the science learning that being implemented is not optimal. It is evidenced by the results of interviews and observations from the principal and all fourth-grade teachers at SD Gugus RA. Kartini, Denpsar Barat, while carrying out learning, there was a problem in science lessons content. It is proved by the number of teachers who complained during interviews related to children having difficulty in understanding the material explained by the teacher, and the number of students who were not interested in science lessons.

The reason is the teacher still uses the lecture method too often, and does not collaborate with the right media. Students are less enthusiast in learning process. When researchers made observations there was still a science learning process that carried out using conventional methods. According to (Yupriyanti, 2015), this conventional learning model is a way to convey teaching material that applied by educators using lectures or oral explanations to students. (Dewi, 2018) also argues that conventional methods of learning are methods used in everyday learning where learning is only teacher-centered and tends to make students inactive. Conventional learning models that emphasize the use of methods commonly used by teachers, providing material through lectures, questions, and assignments (Saptayanti, 2016). Based on the explanation above, it can be concluded that the conventional method is a way of delivering teaching material in teacher-centered learning process and tends to make students inactive in learning process.

Therefore, it is necessary to have creativity in fun learning models. One example of a cooperative learning model is Teams Games Tournament. Teams Games Tournament learning model is a learning model that uses academic games, in this model students become more relaxed in learning. The use of Teams Games Tournament model will be more effective when combined with the use of media, one of the suitable media is Question Card. The Teams Games Tournament learning model is suitable to use in learning activities such as answering questions directly as well as playing, students will compete to answer questions so they will become winners in the academic game. The Teams Games Tournament learning model will be combined with the question card media, question card media plays a role in asking questions given by the teacher, this media will train student readiness, as well as its readiness in answering questions and also training student cohesiveness. Because in answering questions students have to discuss with the group.

Teams Games Tournament (TGT) is cooperative learning that involves all students in the learning process in groups that contain playing elements (Sohimin, 2014). Learning activities with the TGT model allow students to learn to be more relaxed in addition to fostering responsibility, cooperation, healthy competition, and learning involvement. (Suryanata, 2017). (Dwijayanti, 2017) states that the TGT type of cooperative learning consist of five stages, the class presentation, learning in groups, games, tournaments, and team recognition. TGT requires students to be active in learning both physically, mentally, and emotionally to achieve optimal learning outcomes (Astuti, 2017). The advantages of this Teams Games Tournament model are students have freedom to interact to use their opinions in classroom, increase students' self-confidence, decrease in disturbing behavior towards other students, increase student learning motivation, increases kindness, sensitivity, 
tolerance, between students, and between students and teachers, students can study a material or subject (Hikmah, 2018).

The TGT learning model combined with the question card media will make lesson more interesting. A question card is a media which message can stimulate students in learning process (Arsyad, 2017). Question card media allows students to be more relaxed by playing question cards, to fostering responsibility, cooperation, healthy competition, and involvement in learning process (Ariswati, 2018). (Viani, 2017) argued that the question card media can train students' concentration and focus in capturing the information contained in the question card media.

Theoretically, the TGT learning model assisted by question card media has an effective impact on a lesson. Several relevant research results reinforce that the TGT model assisted by question card media has a positive impact on student learning success. (Yunita, 2018) stated that the TGT learning model based on tri hita karana affects science learning interest but there are differences in learning media, (Cahyadi, 2016) stated that the TGT learning model can increase students' science knowledge but there are differences in learning media. (Candra, 2017) stated that the TGT learning model assisted by concept maps has an effect on interest in learning science but there are differences in learning media.

From the explanation that has been conveyed, it is necessary to carry out related research to increase students' insights about the knowledge of nature as well as to increase competence in science knowledge. By applying the TGT model assisted by question card media, it is hoped that it can increase students' competency in science knowledge. So a research was carried out entitled "The Effect of Learning Model Student Team games tournament with Question Card Media on Science Knowledge Competencies of Fourth Grade Students of SD Gugus RA. Kartini, Denpasar barat". Based on this description, the purpose of this study was to determine the significant effect of the TGT learning model assisted by the question card media on the fourth-grade students' competency in science knowledge of SD Gugus RA. Kartini, Denpasar Barat. This research is different from existing research, this research innovates with the assistance of question card media. By applying this model and media, it is hoped that it can solve the problems that exist in SD Gugus RA. Kartini, South Denpasar District.

\section{Research Method}

This research method uses a quasi-experimental research design or quasi-experimental design using a non-equivalent pretest-posttest control group design. (Sugiyono, 2018) quasi-experimental design has a control group but does not have the full function of controlling foreign variables that affect the experimental process. This is due to the ability to observe student behavior and character which may not be the most important when students are not in school, this research also does not require mastery in understanding students' understanding of the treatment that has been done.

According to (Darmadi, 2013) Population is the whole object of research with characteristics such as people, objects, times, and places which are the same. (Syahrun, 2014) explained the population, all objects studied and then summarized in the form of quantitative or qualitative. The population in this study were all four classes in SD Negeri Gugus R.A Kartini Denpasar Barat for the 2019/2020 academic year totaling 12 classes with a total of 392 students. According to (Sugiyono, 2018), the sample is part of the population that has certain characteristics to be the object of research. Random Sampling technique is used when taking research samples. To find an equivalent class academically, a pretest is given for the sample. The t-test is a technique used to analyze the pretest data before it must meet the criteria for the normality test and the homogeneity test. After conducting the equivalence test and the two groups were declared equal, it was continued by drawing the two groups to determine the experimental class and the control class. From the results of the drawing for fourth grade C SD Negeri 19 as the experimental group and fourth grade A SD Negeri 27 as the control group.

The data collection method used in this study is the test method. The instrument used was a science knowledge competency instrument in the form of a multiple-choice objective test usually collected through tests. (Arikunto, 2015) tests are tools used to measure and assess with certain rules. A tool used to measure a natural or social phenomenon being researched or observed is a research instrument (Sugiyono, 2018). The instrument that will be used to measure the competence of science knowledge is an objective test in the form of PGB with 4 choices of options A, B, C, D, totaling 50 items. Each item score 1 if true and score 0 if it is false. From 50 questions, some indicators are guided by the C1-C4 cognitive competences. The preparation of tests is based on basic 
competencies (KD) and indicators that are following the subject matter. The KD and indicators used for the preparation of the instrument are presented in Table 1 below.

Tabel 1. Basic Competencies and Indicators of Science Knowledge Competency Instruments

\begin{tabular}{|c|c|c|}
\hline Basic Competencies (KD) & Indicator & $\begin{array}{c}\text { Cognitive } \\
\text { type }\end{array}$ \\
\hline \multirow{7}{*}{$\begin{array}{l}\text { Identifying the kinds of forces, } \\
\text { including: muscle force, electric } \\
\text { force, magnetic force, gravity force, } \\
\text { and friction force. }\end{array}$} & Explain about forces. & $\mathrm{C} 2$ \\
\hline & Apply muscle forces in everyday life & $\mathrm{C} 3$ \\
\hline & $\begin{array}{l}\text { Identify examples of static electricity } \\
\text { and dynamic electricity }\end{array}$ & $\mathrm{C} 4$ \\
\hline & $\begin{array}{l}\text { Describe the change in the form of } \\
\text { electrical energy }\end{array}$ & $\mathrm{C} 1$ \\
\hline & Identifying examples of magnetic forces & $\mathrm{C} 4$ \\
\hline & $\begin{array}{l}\text { Identify examples of the earth's } \\
\text { gravitational force }\end{array}$ & $\mathrm{C} 4$ \\
\hline & Identify examples of friction forces & $\mathrm{C} 1$ \\
\hline
\end{tabular}

After that, the instrument is tested. Before being tested, content validity and theoretical validity were first carried out, then tested as many as 50 items. The content validity test is carried out by direct testing of judges. While the test item validity test uses the validity test, distinguishing power, difficulty level, and reliability. Many test items that met the requirements in the trial were 30 test items. So, the instruments used in this study have been validated and reliable.

The data analysis method used is descriptive statistics and inferential statistics. Descriptive statistics are used to analyze data by describing the data that has been collected. Descriptive statistics are in the form of average (mean), standard deviation, variance, lowest score, and highest score. Meanwhile, inferential statistics are used to test the hypotheses proposed through the pooled variance t-test. However, before that, the prerequisite test was conducted first, the data normality test using the Kolmogorov-Smirnov test and the homogeneity test with the F test (Fisher).

\section{Result and Discussion}

The data in this study were grouped into two groups: the competence of the science knowledge of students who took part in learning using the TGT learning model assisted by the question card and the competence of the science knowledge of students who took conventional learning. Both samples were given treatment 6 times in the experimental class and 6 times in the control class. At the end of the study, a posttest was given. The following are the results of the posttest scores of the experimental group and the control group which are presented in the following table.

Table 2. Frequency Distribution of Experimental Group Posttest Scores

\begin{tabular}{ccccc}
\hline $\mathbf{X}$ & $\mathbf{X}^{\mathbf{2}}$ & $\mathbf{F}$ & $\mathbf{f X}$ & $\mathbf{f X}^{\mathbf{2}}$ \\
\hline $\mathbf{1 9}$ & 361 & 3 & 57 & 3249 \\
$\mathbf{2 0}$ & 400 & 3 & 60 & 3600 \\
$\mathbf{2 1}$ & 441 & 2 & 42 & 1764 \\
$\mathbf{2 2}$ & 484 & 2 & 44 & 1936 \\
$\mathbf{2 3}$ & 529 & 4 & 92 & 8464 \\
$\mathbf{2 4}$ & 576 & 4 & 96 & 9216 \\
$\mathbf{2 5}$ & 625 & 4 & 100 & 10000 \\
$\mathbf{2 6}$ & 676 & 6 & 156 & 24336 \\
$\mathbf{2 7}$ & 729 & 3 & 81 & 6561 \\
$\mathbf{2 8}$ & 784 & 2 & 56 & 3136 \\
$\mathbf{2 9}$ & 841 & 1 & 29 & 841 \\
\hline
\end{tabular}


Table 3. Frequency Distribution of Control Group Posttest Scores

\begin{tabular}{ccccc}
\hline $\mathbf{X}$ & $\mathbf{X}^{\mathbf{2}}$ & $\mathbf{F}$ & $\mathbf{f X}$ & $\mathbf{f X}^{\mathbf{2}}$ \\
\hline $\mathbf{1 2}$ & 144 & 1 & 12 & 144 \\
$\mathbf{1 8}$ & 324 & 1 & 18 & 324 \\
$\mathbf{1 9}$ & 361 & 1 & 19 & 361 \\
$\mathbf{2 0}$ & 400 & 4 & 80 & 6400 \\
$\mathbf{2 1}$ & 441 & 3 & 63 & 3969 \\
$\mathbf{2 2}$ & 484 & 5 & 110 & 12100 \\
$\mathbf{2 3}$ & 529 & 6 & 138 & 19044 \\
$\mathbf{2 4}$ & 576 & 3 & 72 & 5184 \\
$\mathbf{2 5}$ & 625 & 5 & 125 & 15625 \\
$\mathbf{2 6}$ & 676 & 3 & 78 & 6084 \\
$\mathbf{2 7}$ & 729 & 1 & 27 & 729 \\
\hline
\end{tabular}

Based on the calculation, the posttest mean score of the science knowledge competence in the experimental group was $=23.91$, while the average posttest score for the science knowledge competence in the control group was $=22.48$. For a more complete description of the experimental group and control group data, it can be seen in Table 4 below.

Table 4. Recapitulation of Data Analysis of Gain Normalized Score of Science Knowledge Competence

\begin{tabular}{ccc}
\hline Statistic & $\begin{array}{c}\text { Experimental Group's Natural } \\
\text { Science Competencies }\end{array}$ & $\begin{array}{c}\text { Control Group's Science } \\
\text { Competency }\end{array}$ \\
Mean & 23,91 & 22,48 \\
Standard Deviation & 2,83 & 2,92 \\
Variance & 8,02 & 8,51 \\
Lowest Score & 19 & 12 \\
Highest Score & 29 & 27 \\
\hline
\end{tabular}

Based on Table 4, the average posttest score for the competence of science knowledge in the experimental group is $=23.91$, Standard Deviation $=2.83$, Variant $=8.02$, the lowest score $=19$, and the highest score $=29$. While the average posttest score of the science knowledge competency of the control group is $=22.48$, standard deviation $=2.92$, variant $=8.51$, the lowest score $=12$ and the highest score $=27$.

After obtaining the normalized score gain data competence in scientific knowledge of the experimental and control classes, the next step is to conduct a prerequisite test which includes a normality test and a homogeneity test.

The normality test used in the study used the Kolmogorov-Smirnov technique, with the test criteria using a significance level of 5\%, if $|\mathrm{Ft}-\mathrm{Fs}| \leq$ Kolmogorov-Smirnov, then the data is declared to be normally distributed. While the homogeneity test of variance was carried out on student data of the experimental group and the control group using the $\mathrm{F}$ test with the criteria for testing the score of Fcount $<$ Ftable, so the science knowledge competency data of the experimental and control groups had homogeneous variances. Following are the results of the normality and homogeneity tests of the two sample groups which are presented in Table 5 below.

Table 5. Results of Normality Test for Experiment and Control Groups

\begin{tabular}{|c|c|c|c|c|c|}
\hline No. & Sample group & $\begin{array}{c}\text { Total } \\
\text { sample }\end{array}$ & $\begin{array}{c}\text { Maximum score } \\
\text { Ft-Fs }\end{array}$ & $\begin{array}{l}\text { Kolmogorov- } \\
\text { Smirnov score }\end{array}$ & Information \\
\hline 1 & Eksperimen & 34 & 0,077 & 0,227 & $\begin{array}{c}\text { Normal } \\
\text { Distribution }\end{array}$ \\
\hline 2 & Kontrol & 33 & 0,110 & 0,231 & $\begin{array}{c}\text { Normal } \\
\text { Distribution }\end{array}$ \\
\hline
\end{tabular}


After the data were normally distributed, the variance homogeneity test was then carried out. The homogeneity test of variance was carried out on student data of the experimental group and the control group using Fisher's test with the criteria for testing Fcount < Ftable, so the knowledge competency data of the experimental and control groups had homogeneous variances. Based on the results of the homogeneity test, Fcount $=1.47$. The Ftable score for a significance level of $5 \%$ with $\mathrm{dk}$ numerator $=33$ and $\mathrm{dk}$ denominator $=32$ which is 1.79 so that the ratio Fcount $<$ Ftable is $1.47<1$. The experimental and control class data have homogeneous variances.

Table 6. Homogeneity of Variance Test Results

\begin{tabular}{lllllll}
\hline No & Group sample & Variance & Dk & Fhitung & Ftabel & Information \\
\hline 1 & Experiment & 0,028 & 33 & 1,47 & 1,79 & Homogenous \\
2 & Control & 0,019 & 32 & & & \\
\hline
\end{tabular}

Based on this, the hypothesis testing using the t-test can be done. The hypothesis tested in this study is that there is no significant difference in the competence of scientific knowledge between the groups that are taught using the Teams Games Tournament learning model assisted by the question card media and the group that is taught using conventional learning in the fourth grade of SD Gugus RA Kartini, West Denpasar District, Academic Year 2019 / 2020. The prerequisite test results which include the normality test and the homogeneity of the variance in this study showed that the two groups were normally distributed and had homogeneous variances. The statistical analysis used to test the hypothesis in this study was the t test with pooled variance. Based on the calculation of the $\mathrm{t}$-test, it is obtained that $\mathrm{t}$ count $=3,245$ at the $5 \%$ significance level with dk $34+33-2=65$, obtained $\mathrm{t}$ table $=1.997$. Then tcount $=3,245>\mathrm{ttable}=1,997$ so that Ho is rejected and Ha is accepted so there is a significant difference between the groups that are taught using the TGT model assisted by the question card media on the results of competency in science knowledge.

Table 7. T-Test Analysis of Normalized Gain Score

\begin{tabular}{llcccccc}
\hline No. & Group & Average & $\mathbf{S}^{\mathbf{2}}$ & $\mathbf{N}$ & $\mathbf{t}_{\text {hitung }}$ & $\mathbf{t}_{\text {tabel }}$ & Conclusion \\
\hline 1 & Experiment & 0,396 & 0,028 & 34 & & & $t_{\text {hitung }}>t_{\text {tabel }}$ \\
2 & Control & 0,269 & 0,019 & 33 & 3,245 & 1,997 & \\
\hline
\end{tabular}

Based on the analysis using the t-test, it was found that $t$ count $=3,245$, then compared it with the t-table score with $\mathrm{dk}=65$ at the significance level of $5 \%=1.997$. Because tcount $=3,245>$ $t_{\text {tabel }}=1,997$, the hypothesis states that there is a significant difference in the science knowledge competence of the groups taught through the Teams Games Tournament learning model assisted by question card media and groups that are taught through conventional learning in fourth grade SD Gugus RA Kartini, West Denpasar District. 2019/2020 teaching accepted. The difference in science knowledge between the groups that were taught using the TGT model assisted by the question card media and the groups that were taught conventionally were influenced by the following factors.

First, the TGT learning model has an impact on the competence of science knowledge, increasing the ability to work with groups, being able to train cooperation, and the readiness of students in facing any situation. In this process, students will work together in solving problems given by the teacher. This is in line with (Murdika's, 2018) opinion that the TGT learning model is a group learning model wherein the learning process students can be motivated because in the learning process students are invited to play so that students become more relaxed in learning. (Solihah, 2016) argued that the TGT model can stimulate all students to be active in the learning process because students with less academic abilities will be actively assisted by their colleagues so that in the learning process all students are actively involved so that, in the application of the TGT model all students are required to be able to work together and be active in the learning process. (Respati, 2013) stated that when learning uses the TGT model students are given the freedom to interact socially with their group friends to share information, thereby increasing children's interest in the learning process and also the TGT model involving all students to be active in the learning process.

Second, because of the use of question card media, the question card media also has a good influence on the competence of students' science knowledge because in using this question card media students are required to be alert and able to think critically in reading instructions and the intent of the problems on the questionnaire. So that in the learning process students become 
enthusiastic. This is in line with the opinion of (Kadarwati, 2015) that media question cards help train students' concentration and memory so that students must be ready when the teacher shows the question card media so that students will focus on the teacher and concentrate on capturing the messages contained in the question card media. This is also in line with the opinion of (Febrianti, 2017) that the question card media can train students 'readiness in any situation and can train student concentration in the learning process, the question card media can also attract students' attention because the questions also contain pictures. (Wulandari, 2017) states that question card media can attract students' attention and make students think critically and actively in the learning process.

Third, the combination of the application of the TGT model with the help of question card media which has an impact on science learning. Students are much relaxed in the learning process because in the learning process students are relaxed and students can interact and collaborate with their groups, then assisted by question card media that can attract students' attention. It can also train student concentration in the learning process. This is in line with the opinion (Kurniaty, 2017) that learning by applying the TGT model can improve student science learning outcomes because it can help students be active in the learning process and make students relax while participating in lessons. The TGT cooperative learning model assisted by question card media is an alternative strategy to collaborate with other students and at the same time improve student academic achievement (Gunarta, 2019).

The results of this study are also reinforced by research conducted by (Agustini, 2014) who stated that there are differences in science knowledge competencies between students who are taught with the TGT learning model assisted by environmental media. (Mamanda, 2018) stated that there are differences in Civics knowledge competencies between students who are taught with the TGT learning model assisted by the printed card media around. (Putri, 2019) stated that there are differences in science knowledge competencies between students who are taught with the Group Investigation learning model assisted by Question Card media. (Maulidina, 2017) who states that there are differences in the competence of science knowledge between students who are taught with the TGT learning model assisted by TTS media. (Septiawan, 2018) stated that there are differences in the competence of science knowledge between students who are taught with the TGT learning model assisted by Audio Visual media.

The difference in the results of competency in scientific knowledge could be seen from the learning process that has been carried out on two sample groups, the results of hypothesis testing, and is seen based on the mean scores in the two groups. Based on this explanation, it was stated that the TGT learning model assisted by question card media had an effect on the competence of fourthgrade students of SDN Gugus R.A Kartini Denpasar Barat for the 2019/2020 academic year.

\section{Conclusion}

Based on the results of the hypothesis test analysis, there are differences in the normalized gain score of the two class groups. This is evidenced by the $t$-test analysis obtained tcount $=3,245$ at the significance level with $d k=65$ obtained $t_{\text {table }}=1.997$. Because $t_{\text {count }}=3,245>t_{\text {tabel }}=1,997$, Ho is rejected and $\mathrm{Ha}$ is accepted which states that there is a significant difference in the competence of science knowledge between groups of students who are taught through the TGT learning model assisted by question card media and groups of students who are taught conventionally in fourth grade SD Negeri Gugus RA Kartini, West Denpasar, Academic Year 2019/2020. Suggestions that can be submitted are that the teacher is expected to be able to apply a variety of innovative learning models and the use of media or props that can make the learning atmosphere fun and meaningful for students. The school is expected to be able to use research results as a reference in developing variations in the more innovative learning process. For other researchers, to be able to find variations in more innovative learning models that are following the implementation of the 2013 curriculum, which can contribute to the field of education.

\section{References}

Agustini, M. (2014). Pengaruh Model Pembelajaran TGT berbantuan Media Flip Chart Terhadap Hasil Belajar IPA Siswa Kelas V SD. Jurnal Mimbar PGSD Universitas Pendidikan Ganesha Jurusan PGSD, 2(1).http://dx.doi.org/10.23887/jijpgsd.v2i1.3097

Arikunto, S. (2015). Dasar-Dasar Evaluasi Pendidikan. PT Bumi Aksara. 
Ariswati, N. P. E. A. (2018). Pengaruh Model Pembelajaran Problem Based Learning Terhadap Hasil Belajar Matematika Siswa Kelas V Sd Negeri Nanggulan. PGSD Universitas Pendidikan Ganesha Mimbar PGSD, 6(4).

Arsyad, A. (2017). Media Pembelajaran. PT. Rajagrafindo Persada.

Astuti, F. K. (2017). Penerapan Model Pembelajaran Teams Games Tournamen tuntuk Meningkatkan Keaktifan Dan Hasil Belajar Ipa Pada Siswa Sekolah Dasar. Jurnal Didaktika Dwija Indria (SOLO), $5(5)$,

Awang, S. I. (2015). Vox Edukasi Vol 6, No 2 Nopember 2015 Nelly Wedyawati , Deskripsi Analisis... 143. Vox Edukasi, 6(2),.

Cahyadi, M. I. W. (2016). Penerapan Model Tgt Meningkatkan Penguasaan Kompetensi Pengetahuan Ipa Siswa Kelas Vb Sd Negeri 8 Pemecutan. MIMBAR PGSD Undiksha, 4(1), 1-10.

Candra, N. M. Y. (2017). Pengaruh Model Pembelajaran Kooperatif Tipe Teams Games Tournament Berbantuan Peta Konsep Terhadap IV SD Gugus Letda Made Putra. Mimbar PGSD, 5(2).

Darmadi, H. (2013). Metode Penelitian Pendidikan. Alfabeta.

Devitasari. (2014). Indonesian Journal of Conservation. Indonesian Journal of Conservation, 3(1),

Dewi, N. P. M. C. (2018). Pengaruh Model Pembelajaran Crh Berbantuan Media Question Cards Terhadap Hasil Belajar Matematika Siswa Kelas IV SD. E-Journal PGSD Universitas Pendidikan Ganesha Jurusan PGSD, 4(1),

Dwijayanti, K. (2017). Model Pembelajaran Kooperatif Tipe Tgt Berbantuan Media Questions Box Berpengaruh Terhadap Kompetensi Pengetahuan Ipa Universitas Pendidikan Ganesha. PGSD Universitas Pendidikan Ganesha Mimbar PGSD, 5(2).

Febrianti, I. (2017). , Susilo Tri Widodo. Jurnal Kreatif, 14692(September 2017),

Gunarta, I. G. (2019). Pengaruh Model Pembelajaran TGT Berbantuan Media Question Card Terhadap Hasil Belajar IPA. Jurnal Pedagogi Dan Pembelajaran, 1(2), 112.

Hikmah, M. (2018). Penerapan Model Pembelajaran Team Games Tournament (TGT) Terhadap Motivasi dan Hasil Belajar Peserta Didik pada Materi Dunia Hewan Kelas X di SMA Unggul Negeri 8 Palembang. Jurnal Pembelajaran Biologi, 5(1).

Insani, M. D. (2016). Studi Pendahuluan Identifikasi Kesulitan Dalam Pembelajaran Pada Guru Ipa Smp Se-Kota Malang Metri Dian Insani Kemampuan siswa SMP Indonesia Study ) dan PISA ( Programme International Indonesia masih berada di peringkat bawah isi materi (konten) yang ak. Jurnal Pendidikan Biologi, 7(2),

Kadarwati, S. (2015). Efektivitas Model Pembelajaran Huitt Dengan Media Question Card Dan Model Pembelajaran Pq4R Dengan Media Flip Boox Maker Terhadap Hasil Belajar Logika Matematika Siswa Kelas X Sma Negeri I Semarang. Jkpm, 2(2).

Kurniaty, D. F. (2017). Tjipto Haryono 2). Pensa, 05(1993),

Mamanda, S. (2018). Penerapan Model Pembelajaran Kooperatif Tipe Teams Game Tournaments (TGT) untuk Meningkatkan Hasil Belajar Ilmu Pengetahuan Sosial. Jurnal Penelitian Dan Pengembangan Pendidikan, 2(3),

Maulidina, Z. (2017). Pengaruh Model Pembelajaran Kooperatif Tipe Gi. JISD, 8(2),

Metta Ariyanto. (2016). e-ISSN: 2503-3530 p-ISSN 2406-8012 Peningkatan Hasil Belajar Ipa Materi Kenampakan Rupa Bumi Menggunakan Model Scramble. Peningkatan Hasil Belajar Ipa Materi Kenampakan Rupa Bumi Menggunakan Model Scramble, 3(2),

Muakhirin, B. (2015). Peningkatan Hasil Belajar Ipa Melalui Pendekatan Pembelajaran Inkuiri Pada Siswa Sd. Jurnal Ilmiah Guru Caraka Olah Pikir Edukatif, 1(1).

Murdika. (2018). Penerapan Model Pembelajaran Kooperatif Tipe TGT Untuk Meningkatkan Motivasi dan Aktivitas Belajar Peserta Didik Kelas XMIA-3 SMAN 1 Tanete Rilau (Studi pada Materi Pokok Ikatan Kimia dan Bentuk Geometri). Chemica: Jurnal Ilmiah Kimia Dan Pendidikan Kimia, 19(1), 
Putri, N. K. I. P. (2019). Pengaruh Model Pembelajaran Group Investigation Berbantuan Media Questions Card Terhadap Pemahaman Konsep \dan Keterampilan Berpikir Kritis IPA. Thinking Skills and Creativity Journal, 1(2),

Respati, D. A. (2013). Jupe UNS, Vol 1, No 2, Hal 1 s/d 10 Agustina Dwi Respati,. Jupe UNS, 1(2).

Salim, S. dan. (2014). Metode Penelitian Kuantitatif. Citapustaka Media.

Saptayanti, E. G. A. K. (2016). Pengaruh Model Pembelajaran Kooperatif Tipe Tgt ( Teams Games Tournament ) Terhadap Hasil Belajar Matematika Universitas Pendidikan Ganesha. PGSD Universitas Pendidikan Ganesha Jurusan PGSD, 4(1).

Septiawan, E. I. M. A. (2018). Pengaruh Model Pembelajaran Time Token Berbantuan Media Audio Visual Terhadap Hasil Belajar IPS. Jurnal Penelitian Dan Pengembangan Pendidikan, 2(3),

Setianingsih, A. I. G. A. A. . (2019). Pengaruh Model Pembelajaran Children'S Learning in Science Berbantuan Media Audio Visual Terhadap Kompetensi Pengetahuan Ipa. Mimbar Ilmu, 24(1),

Sohimin, A. (2014). 68 Model Pembelajaran Inovatif Dalam Kurikulum 2013. Ar-ruzz media.

Solihah, A. (2016). Pengaruh Model Pembelajaran Team Games Tounamaent(TGT) Terhadap Hasil belajar Matematika. Jurnal SAP Vol., 1(1),

Sugiyono. (2018). Metode Penelitian Kuantitatif, Kualitatif, dan $R \& D$. Alfabeta.

Sulthon. (2016). Pembelajaran Ipa Yang Efektif Dan Menyenangkan Bagi Siswa Madrasah Ibtidaiyah (Mi). Elementary, 4(1),

Suryanata, I. K. A. (2017). Pengaruh Model Pembelajaran Kooperatif Tipe Teams Games Tournament Terhadap Hasil Belajar Matematika. JKPM (Jurnal Kajian Pendidikan Matematika), 2(2),

Susanto, A. (2016). Teori Belajar dan Pembelajaran di Sekolah Dasar. Kharisma Putra Utama.

Viani, S. D. (2017). Perbandingan Hasil Belajar Siswa Menggunakan Media Call Card dan Truth and Dare. Pendidikan Dan Ilmu Kimia, 1(1),

Wulandari. (2017). Penggunaan Question Card Dalam Model Pembelajaran Pbl Dan Problem Solving Terhadap Hasil Belajar Matematika. EKUIVALEN - Pendidikan Matematika, 28(1).

Yunita, D. N. K. (2018). Pengaruh Model Pembelajaran Kooperatif Tipe Pair Check. Jurnal Penelitian Pendidikan Guru Sekolah Dasar, 6(6), 96-107.

Yupriyanti, N. L. (2015). Pengaruh Model Pembelajaran Generatif Berbantuan Media Konkret Terhadap Hasil Belajar Ipa Siswa Kelas V Sd Gugus 1 Manggis Kecamatan Manggis Kabupaten Karangasem Tahun Ajaran 2014/2015. MIMBAR PGSD Undiksha, 3(1). 